JOURNAL OF HEALTH SCIENCE AND PREVENTION

http://jurnalfpk.uinsby.ac.id/index.php/jhsp

ISSN 2549-919X (e)

\title{
The Effect of Implementation of Patient Orientation Program on Patient's Adaptability
}

\author{
Nur Hidayah', Dardin², Dian Pratiwi Putri ${ }^{3}$ \\ 1)Nursing Lecturer at the Faculty of Medicine and Health Sciences UIN Alauddin Makassar \\ 2)Education and Training Division, Bhayangkara Hospital, Makassar \\ 3)Nursing Department, Faculty of Medicine and Health Sciences, UIN Alauddin, Makassar \\ Correspondence e-mail: nur.hidayah@uin-alauddin.ac.id
}

DOI: http:// doi.org/10.29080/jhsp.v3i3S.305

\section{Keywords}

Patient Orientation Adaptability

\begin{abstract}
New patients undergoing inpatient services at the hospital should be given an orientation program to the care environment. The room orientation program is not only for patients but also for families who will be involved in the treatment process. The purpose of this study was to determine the effect of the implementation of patient orientation program on patient's adaptability in the internal care room of the Sheikh Yusuf Hospital, Gowa Regency. The design used was pre-experimental in one subject group (one-group pretest and posttest) with the population of all samples obtained by Internal Care at Syekh Yusuf Hospital in Gowa Regency. The sample size was 21 respondents using accidental sampling. The independent variable was the implementation of patient orientation program and the dependent variable was the patient's adaptability. The methodof collecting data was a questionnaire. Data were analyzed using Wilcoxon signed rank test.The result of the study showed that there was an effect of the implementation of the patient orientation program on patient's adaptability ( $p=0,000 \mathrm{Z}=-4,059)$.As the conclusion, if nurses carry out orientation programs to patients according to the procedure, the patient will be able to adapt to the environment and the treatment process.Further research on the effect of implementing an orientation program on patient's adaptability should be directed to innovative models of patient orientation program.
\end{abstract}

\section{Introduction}

Hospital is a service installation that provides outpatient services, inpatient care, which includes medical services for nursing and medical support. As one of the integrative and comprehensive health service installations, hospitals have a pivotal role in health services. The quality of the hospital as an institution that produces health care technology products certainly depends also on the quality of medical and nursing services provided to patients (1). Provision of incorrect and timely orientation can have an impact on patient/family disobedience in carrying out the rules in hospital (2).

Most patientsvisit the hospital without preparation and without prior planning. However, in any way the clients enter the hospital, they might feel anxious, uncomfortable and afraid of not being able to adapt to their surroundings. This phenomenon for nurses is common, but for clients and their families, the internal care room is very frightening and strange. Therefore, accepting new patients needs to be orientated (3).

Patient orientation is necessary to be heldbecause patients in hospitals often experience anxiety or fear, insecurity, and comfort. So that patients are difficult to adapt to the environment in the hospital. Thus, each patient who has just entered the treatment room must have an orientation to the patient or family by the nurse so that the patient is able to adapt to the care environment.

Based on the above phenomenon, that nurses who carry out orientation to new patients admitted to the hospital are rarely done. Therefore, patients who experience anxiety, fear, are difficult to adapt to the environment in the ward. Especially in patients who are first treated in the treatment room. Hence, the researchers were interested in conducting a study on "The Effect of Application of Patient Orientation Programs to the Adaptation Ability of Patients in the Internal Care Room of Syekh Yusuf Regional Hospital, Gowa Regency".

\section{Method}


The design of this study was pre-post experiment by involving one group of subjects. This research was conducted by firstly giving questionnaires to the respondents then giving an intervention. After that,they were given the same questionnaires as before.

The sampling technique in this study was accidental sampling with inclusion criteria (1) patients were first treated (2) patientswere with full awareness (3) patients were able to communicate well (4) patients wanted to be respondents. Exclusion criteriawere uncooperative patients and patientswith weak general condition.

\section{Result \\ Respondent Charasteristics}

Table 1

Frequency Distribution of Respondents Based on the Characteristics of Respondents

\begin{tabular}{|c|c|c|c|}
\hline No & Charasteristics & $\mathbf{F}$ & $\%$ \\
\hline \multirow[t]{4}{*}{1} & Age & & \\
\hline & $<21$ years old & 3 & 14.3 \\
\hline & 21-35 years old & 9 & 42.9 \\
\hline & $>35$ years old & 9 & 42.9 \\
\hline \multirow[t]{5}{*}{2} & Education Level & & \\
\hline & Less than elementary level & 1 & 4.8 \\
\hline & Elementary school & 5 & 23.8 \\
\hline & Junior high school & 5 & 23.8 \\
\hline & High school & 10 & 47.6 \\
\hline \multirow[t]{4}{*}{3} & Jobs & & \\
\hline & Unemployed & 8 & 38.1 \\
\hline & Employee & 8 & 38.1 \\
\hline & Others & 5 & 23.8 \\
\hline \multirow[t]{2}{*}{4} & Religion & & \\
\hline & Islam & 21 & 100 \\
\hline \multirow[t]{3}{*}{5} & Marital status & & \\
\hline & Married & 10 & 47.6 \\
\hline & Single & 11 & 52.4 \\
\hline
\end{tabular}

Source:Primary data, 2014

Most of respondents were 21-35 years old and $>35$ years old, which were 9 respondents (42.9\%). The highest level of education of the respondents was Senior High School,10 respondents (47.6\%). The majority of respondents' jobs were self-employed and did not work at 8 respondents (38.1\%). The number of respondents who were Muslim was 21 (100\%). Most respondents were single at 11 respondents (52.4\%).

\section{The effect of implementation of patient orientation program on patient's adaptability}

Table 2

The Effect of Implementation Patient Orientation Program on Patient's Adaptability

\begin{tabular}{llcc}
\hline Patient orientation & \multicolumn{1}{c}{ Adaptability } & $p$ \\
& Able & Unable & $p<0.0001$ \\
\hline Pre-orientation & 0 & 21 & \\
Post-orientation & 21 & 0 &
\end{tabular}

The result of the statistical test showed a $p$ value of $<0.0001$, which means that there was an effect of the application of a patient orientation program to the adaptability of patients in Syech Yusuf Hospital, Gowa Regency.

\section{Discussion}

Based on the result of the research that has been carried out in Internal Care Room of Syekh Yusuf Hospital in Gowa Regency, all respondents which were 21 respondents (100\%) before being applied to 
patients' orientation were unable to adapt. After the patient orientation, all respondents were able to adapt. Statistical test showed that the value of $p=0,000$ was smaller than $\leq 0,05$, meaning that there was an effect of the application of the patient orientation program to patients' adaptability in Syekh Yusuf Hospital, Gowa Regency.

Patients when admitted to hospital before being applied to orientation patients often feel insecure, uncomfortable and lonely because none of patients know in the treatment room except the family who looks after them. This is not only experienced by patients but also with their families. According to Purwadarminta, this can be caused by ignorance of activities in the hospital and requires further explanation, the inability to adapt can have a negative impact where patients can show hostility, the response to the environment decreases, and makeit difficult to work with nurses (4).

In the context of nursing, orientation means introducing everything about the hospital including the hospital environment, health personnel, regulations, procedures, and other patients. Nurses and patients work together to analyze situations so that they can recognize, clarify and determine the consistency of a problem.Thus, patients can prepare themselves from anxiety towards more constructive conditions in dealing with the problem (4).

The results of this study showed that patients who were first treated in the treatment room faced a new environment so that an adaptation was needed. Things that were necessary to be oriented were the introduction of the room, the nurse who cared for, the procedure of action, other patients, and the rules of the room.

Other factors that influenced such as most respondents (42.9\%) in this study were over 35 years old. Hence,the maturity age has a mature personality and was easier and faster to adapt in the internal care room. The level of education of patients was also mostly those who have graduated from high school which were 10 respondents (47.6\%). This madethem easier to understand what had been explained by the nurse.

According to Gillies (2006), giving orientation in accordance with the philosophy is fulfilling the needs of patients/families, the physical needs of patients and focusing one by one on the patient's security needs and affection and appreciation which will provide experience that can lead to achieving patient selfactualization to patient compliance with existing regulations and patients can also adapt to the surrounding environment (5).

According to Barbara (1996), the implementation of optimal orientation will lead to an understanding of the patients about their condition and avoid patients from negative perceptions that arise due to ignorance of patients with their condition (6). This opinion is also supported by Rahmat Adi Surya (2012) who said that with orientation, nurses and patients together identify problems and mutual trust (7).

Patients in the treatment room experienced fear of something unknown and procedures that might hurt them. Thiswas probably the most common cause of insecurity and comfort or the inability of patients to adapt as long as the patient was treated. One of the goals of care is to provide a good orientation so that patients who receive information clearly will be able to carry out treatment independently.

The inability of patients to adapt due to separation from their families, routine changes in habits, new environments, and painful procedures could cause ineffective coping which could be seen from the behavior of patients who appeared unsafe and uncomfortable in the treatment room.

Adaptation is a process of change that accompanies individuals in responding to changes that exist in the environment and can influence the body's needs both physiologically and psychologically which will produce adaptive behavior. The result of this adaptive behavior can be all responses by trying to maintain the balance of a situation. In addition, adaptive response is also a totality of responses from humans as holistic creatures, which require time in the process of adjustment and each person will be different in the process of adjustment, sometimes people are quick to adapt, but there is a time when adaptation is slow and all adaptive responses are not enough in facing changes but sometimes found inadequate and basically tiring adaptive responses considering the need for sufficient energy and resources (8).

\section{Conclusion}

This study showed that the orientation program of new patients in Syech Yusuf Hospital provided a significant influence on the ability of patients to adapt to the environment in the treatment room. The orientation program carried out in accordance with procedures in the form of orientation to the room, health personnel, action procedures, regulations, and other patients, was basic information for patients.

\section{References}

1. Nursalam, Nur M. Manajemen Keperawatan: Aplikasi dalam Praktik Keperawatan Profesional. Jakarta: Salemba Medika; 2012 
2. Pakaya N, Nontji W, As'ad S. Pengaruh Orientasi Pasien Terhadap Kepatuhan Pasien/Keluarga Dalam Menjalankan Aturan di Rumah Sakit UNHAS Makassar. 2013;12.

3. Wellem, Oktovina. Pengaruh Orientasi Terhadap Tingkat Kecemasan Pasien yang Dirawat Di Ruangan Internal Rsud Kabupaten Papua Barat. Prosiding Konferensi Nasional PPNI Jawa Tengah 2013; 2013.

4. Poerwadarminta WJS. Kamus umum bahasa Indonesia [Internet]. Jakarta: Balai Pustaka; 1966 [cited 2019 Dec 10]. Available from: https://books.google.com/books/about/Kamus_umum_bahasa_Indonesia.html?hl=id\&id=hfwXAAAAIAAJ

5. Dee Ann Gillies Rn. Manajemen Keperawatan Suatu Pendekatan Sistem.2 Ed. Chicago: W.B. Saunders Company; 2006.

6. Barbara C. Perawatan Medikal Bedah (Suatu Pendekatan Proses Keperawatan). Bandung: Yayasan IAPK Pajajaran; 1996.

7. Surya RA. Pengaruh Orientasi Terhadap Tingkat Kecemasan Pasien Yang Dirawat Di Ruang Interna Rsud Labuang Baji Makassar. [Makassar]: Uin Alaudin; 2012.

8. Hidayat A. Pengantar Konsep Dasar Keperawatan. 2 ed. Jakarta: Salemba Medika; 2008. 